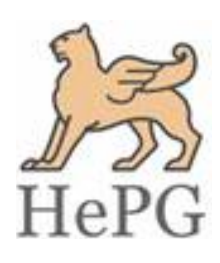

ISSN: 2348-1900

Plant Science Today

http://www.plantsciencetoday.online

\title{
Organoleptic and grain quality traits of aromatic rice varieties as influenced by supplementation of $\mathrm{Zn}$ and 2- acetyl-1-pyrroline
}

Tuhin Suvra Roy ${ }^{1^{*}}$, Anup Roy ${ }^{2}$, Mohammed Ali $^{2}$, Rajesh Chakraborty ${ }^{1}$, Maruf Mostofa ${ }^{2}$, Anil Kumar Mahato ${ }^{3}$, Md. Mehedi Hasan Sumon $^{1} \&$ Nahid Sultana ${ }^{4}$

${ }^{1}$ Department of Agronomy, Sher-e-Bangla Agricultural University, Dhaka 1207, Bangladesh

${ }^{2}$ Institute of Seed Technology, Sher-e-Bangla Agricultural University, Dhaka 1207, Bangladesh

${ }^{3}$ Department of Horticulture, Sher-e-Bangla Agricultural University, Dhaka 1207, Bangladesh

${ }^{4}$ Department of Agricultural Chemistry, Sher-e-Bangla Agricultural University, Dhaka 1207, Bangladesh

\section{Article history}

Received: 28 July 2019

Accepted: 26 September 2019

Published: 20 October 2019

\section{Publisher}

Horizon e-Publishing Group

\section{*Correspondence}

Tuhin Suvra Roy

区tuhinsuvraroy@sau.edu.bd

\begin{abstract}
Aromatic rice fetches premium prices in world markets due to its pleasant smell and enchanting flavor. In Bangladesh, the quality of aromatic rice is much inferior than those of other rice growing countries because of lack of improved variety and judicious agronomic management. Selection of appropriate variety and supplementation zinc (Zn) and 2-acetyl-1pyrroline (2-AP) can improve the aroma. The present study exhibited the effects of 2-AP and $\mathrm{Zn}$ supplementation on yield and quality of aromatic rice. Two well-known aromatic cultivars, BRRI dhan 80 and BRRI dhan34, were cultured separately in pot supplemented with 2-AP and $\mathrm{Zn}$. The results showed that supplementation of 2-AP and /or Zn along with conventional practices had significant effects on organoleptic and some quality parameters studied in this study. The concentration of $2 \mathrm{AP}$ and $\mathrm{Zn}$ in rice grain increased with increasing their application rate. Additionally, grain 2-AP concentrations were significantly and positively correlated with organoleptic characters. Interactions of both these elements with the complex process of 2-AP formation remain to be explored.
\end{abstract}

Keywords: Zn; 2-acetyl-1-pyrroline; grain 2-AP; protein; amylase; aromatic rice.

Citation: Roy T S, Roy A, Ali M, Chakraborty R, Mostofa M, Mahato A K, Sumon M H, Sultana N Organoleptic and grain quality traits of aromatic rice varieties as influenced by supplementation of Zn and 2-acetyl-1-pyrroline. Plant Science Today 2019;6(4):518-527. https://doi.org/10.14719/pst.2019.6.4.620

Copyright: (C) Roy et al. (2019). This is an open-access article distributed under the terms of the Creative Commons Attribution License, which permits unrestricted use, distribution, and reproduction in any medium, provided the original author and source are credited (https://creativecommons.org/licenses/by/4.0/).

Indexing: Plant Science Today is covered by Scopus, Web of Science, BIOSIS Previews, ESCI, CAS, AGRIS, CABI, UGC-CARE, Google Scholar, etc. Full list at http://www.plantsciencetoday.online

\section{Introduction}

Fine rice is mainly used by the people in the preparation of palatable dishes and sold at a higher price in the market due to its special appeal for aroma and acceptability. Rice imports hit the alltime high during the current financial year. So, the country has imported 3.7 million tons and the import might surpass 4.0 million tons by the end of next June month. So far, the public sector has imported over 1.0 million tons, while the private sector import also increased to a record 2.65 million tons, of which 90 per cent were from India and of which demand for the fine-quality rice now is 
around $30 \%$ (1). Most of the rice exported in the international market is par-boiled (Atap) and sticky rice. But 95 per cent of rice produced in Bangladesh is hard grained with hardly any demand in the international market. However, Bangladesh exports about 50,000 tons of fragrant rice to the Middle East, the US and Europe every year. The main consumers of this rice are expatriate Bangladeshis (2). Still Bangladesh has a bright prospect for export of this fine rice thereby earning foreign exchange. Islam (3) observed that the yield of aromatic rice is much lower than those of other rice growing countries because of lack of improved variety and judicious fertilizer management. Selection of appropriate variety and application of integrated nutrient management, the yield can be increased. Another drawback is that the aroma of rice is gradually decreased with advancing storage period. Researchers have identified approximately 200 different volatile compounds that contribute to rice aroma. Mathure $(4,5)$ reported that 2-acetyl-1-pyrroline (2-AP), (E)2-nonenal, octanal, decanal (E, E)-2-decenal, hexanal, 4-vinylphenol, guaicol, indole and vanillin etc are the key contributors to rice aroma. Among these complicated multiple volatile substances that have been detected in fragrant rice, 2-AP was identified as the most prominent compound contributing to aromatic characters of scented rice $(6,7)$. The 2-AP production is genetically controlled but the concentration is also actually affected by other factors such as environment, climate, location and nutrient elements (8). These findings imply that good management on cultivation conditions could enhance 2-AP production and increase yield in fragrant rice (9). So yield and grain quality of aromatic rice may be improved by applying optimum amount of specific fertilizers and can also increase the aroma by applying with 2-AP in soil. Shivay (10) observed that the application of $7.5 \mathrm{~kg} \mathrm{Zn} \mathrm{ha}{ }^{-1}$ increased $\mathrm{Zn}$ concentrations in the grain and straw of aromatic rice and Yadi et al. (11) also reported that the application of $\mathrm{Zn}$ is better for grain yield and some quality traits of rice. So, zinc may have the positive relation with aroma of rice. Moreover Yoshihashi (9) pointed out that $\mathrm{N}, \mathrm{P}, \mathrm{Ca}, \mathrm{Zn}, \mathrm{Mn}$ and $\mathrm{Mg}$ affects aroma formation in aromatic rice and showed a significant relationship with 2-AP biosynthesis. Among these, $\mathrm{Zn}$ is the key input for improving the grain quality of aromatic rice. Therefore, a study plan will be undertaken to find out the effect of $\mathrm{Zn}$ and 2-AP supplementation on organoleptic and grain quality traits of aromatic rice varieties.

\section{Materials and Methods}

\subsection{Experimental period and site}

The pot experiment was conducted in the farm shade house of Sher-e-Bangla Agricultural University (SAU), Dhaka-1207, at Aman season during June, 2018 to November, 2018. The experimental area was belonged to $23^{\circ} 7^{\prime} \mathrm{N}$ latitude and $93^{\circ} \mathrm{E}$ ' longitude at an altitude of 8.6 meter above the sea level. The experimental site belongs to the agro-ecological zone of "Madhupur Tract", AEZ-28. The soil was also characterized by pH-5.62 and organic carbon$0.456 \%$ (Analyzed from Soil Resources Development Institute, Dhaka). The research area is under sub-tropical humid climatic conditions with a total annual rainfall was $24.23 \mathrm{~mm}$ with average monthly maximum and minimum temperature of $29.64^{\circ} \mathrm{C}$ and $14.91^{\circ} \mathrm{C}$, respectively.

\subsection{Planting material}

Popular two aromatic rice varieties viz., BRRI dhan 34 and BRRRI dhan 80 were used in this study. The seeds of the test crop i.e., BRRI dhan 34 and BRRRI dhan80 were collected from Bangladesh Rice Research Institute (BRRI), Joydebpur, Gazipur (Plant authentication number: Khaskani used to select BRRI dhan34 by local selection process and BR7697-15-4-4-2-2 for BRRI dhan80).

\subsection{Treatments and design}

The present experiment comprised of three factors

\begin{tabular}{|c|c|c|}
\hline $\begin{array}{l}\text { Factor A: } \\
\text { Aromatic } \\
\text { rice }\end{array}$ & $\begin{array}{c}\text { Factor B: } \\
\text { Zinc dose (3) }\end{array}$ & $\begin{array}{c}\text { Factor B: } \\
\text { 2-AP } \\
\text { concentration (3) }\end{array}$ \\
\hline $\begin{array}{l}\text { varieties } \\
\text { (2) } \\
\text { 1. BRRI } \\
\text { dhan34 }\end{array}$ & $\begin{array}{l}\text { 1. } \mathrm{Zn}_{0}=10 \mathrm{~kg} \\
\mathrm{ZnSO}_{4} / \text { ha(Recomm } \\
\text { ended dose) }+0 \mathrm{~kg} \\
\mathrm{ZnSO}_{4} / \text { ha } \\
\text { (supplementation) }\end{array}$ & $\begin{array}{l}\text { 1. } \mathrm{AP}_{0}=0 \mathrm{ml} 2-\mathrm{AP} \\
\text { mother solution } / \mathrm{L} \\
\text { water in } 5 \mathrm{~kg} \text { pot } \\
\text { soil }\end{array}$ \\
\hline \multirow[t]{2}{*}{$\begin{array}{l}\text { 2. BRRI } \\
\text { dhan } 80\end{array}$} & $\begin{array}{l}\text { 2. } \mathrm{Zn}_{1}=10 \mathrm{~kg} \\
\mathrm{ZnSO}_{4} / \mathrm{ha}+2 \mathrm{~kg} \\
\mathrm{ZnSO}_{4} / \mathrm{ha} \\
\text { (supplementation) }\end{array}$ & $\begin{array}{l}\text { 2. } \mathrm{AP}_{1}=0.503 \mathrm{ml} 2- \\
\mathrm{AP} \text { mother } \\
\text { solution/L water in } \\
5 \mathrm{~kg} \text { pot soil }\end{array}$ \\
\hline & $\begin{array}{l}\text { 3. } \mathrm{Zn}_{2}=10 \mathrm{~kg} \\
\mathrm{ZnSO}_{4} / \mathrm{ha}+4 \\
\mathrm{kgZnSO}_{4} / \mathrm{ha} \\
\text { (supplementation) }\end{array}$ & $\begin{array}{l}\text { 3. } \mathrm{AP}_{2}=1.006 \mathrm{ml} 2- \\
\mathrm{AP} \text { mother } \\
\text { solution/L water in } \\
5 \mathrm{~kg} \text { pot soil }\end{array}$ \\
\hline
\end{tabular}

The experiment was laid out in a $2 \times 3 \times 3$ factorial design with three replications. There were 18 treatment combinations. The total numbers of unit pots were 54 .

\subsection{Crop management}

Healthy seeds were selected by specific gravity method and then immersed in water bucket for 24 hours and then those were kept tightly in gunny bags. The seeds started sprouting after 48 hours and were sown after 72 hours. The seedbed was prepared with $1 \mathrm{~m}$ wide adding nutrients as per the requirements of soil. Seed were sown in the seed bed @ $70 \mathrm{~g} \mathrm{~m}^{-2}$ on 10 June, 2018. Cowdung was applied in unit pot @ 8 ton per hectare and chemical fertilizer as urea, TSP, MOP, Gypsum, and Zinc sulphate, was applied @ 270-130-120-70-10 kg per hectare, respectively. All the fertilizer was applied as basal dose except urea which was 
applied as top dressing in 3 equal instalments and at 15 Days after transplanting (DAT), tillering and panicle initiation stages. The seedlings were transplanted in the pot on 15 July, 2018. The irrigation was provided to maintain a constant level of standing water up to $6 \mathrm{~cm}$ was equipped with watering cane for continuous flood irrigation throughout the rice-growing season. Different intercultural operations (Gap filling, removal of weed and plant protection measures) were done as per when needed.

\subsection{Recording of data}

\subsubsection{Effective tillers per hill}

The total numbers of effective tillers per hill were counted as the number of panicle bearing tillers during harvesting. Data on effective tillers hill ${ }^{-1}$ were counted from 5 selected hills and average value was recorded.

\subsubsection{Filled grains per panicle}

The total numbers of filled grains were collected randomly from selected 5 panicle of a plot on the basis of grain in the spikelet and then average numbers of filled grains per panicle was recorded.

\subsubsection{Weight of 1000-grains}

One thousand grains were counted randomly from the total cleaned harvested grains and then weighed in grams and recorded.

\subsubsection{Grain yield per plant}

The crops were harvested according to maturity from pot. After threshing, cleaning and sun drying, the grain weight was recorded in gram per plant.

\subsection{5 $\mathrm{Zn}$ content in rice}

The dried samples of rice grains were ground for $\mathrm{Zn}$ analyses with a milling machine and sieved. Thereafter, the samples were digested using a diacid [perchloric acid $\left(\mathrm{HClO}_{4}\right)+$ nitric acid $\left(\mathrm{HNO}_{3}\right)$ in 3:10 ratio] method. After digestion in the aliquot of samples, total Zn was estimated with the help of atomic absorption spectrophotometer (Perkin Elmer; Model-A. Analyst 100) as described by (12).

\subsubsection{Grain-2AP content in rice}

The 2-AP content in grain was estimated by using method described by (13), prior to analysis, grains were ground by mortar and pestle. Approximately $10 \mathrm{~g}$ grains were mixed homogeneously with 150 $\mathrm{ml}$ purified water into a $500 \mathrm{ml}$ round-bottom flask attached to a continuous steam distillation extraction head. The mixture was boiled at $150^{\circ} \mathrm{C}$ in an oil pot. A $30 \mathrm{ml}$ aliquot of dichloromethane was used as the extraction solvent and was added to a $500 \mathrm{ml}$ round-bottom flask attached the other head of the continuous steam distillation apparatus, and this flask was boiled in a water pot at $53^{\circ} \mathrm{C}$. The continuous steam distillation extraction was linked with a cold water circulation machine in order to keep temperature at $10^{\circ} \mathrm{C}$. After approximately $35 \mathrm{~min}$, the extraction was complete. Anhydrous sodium sulfite was added to the extract to absorb the water. The dried extract was filtered by organic needle filter and analyzed for 2-AP content by GCMS-QP 2010 Plus. High purity helium gas was used as the carrier gas at flow rate of $2 \mathrm{ml} / \mathrm{min}$. The temperature gradient of the GC oven was as follows: $40^{\circ} \mathrm{C}(1 \mathrm{~min})$, increased at $2^{\circ} \mathrm{C} \min ^{-1}$ to $65^{\circ} \mathrm{C}$ and held at $65^{\circ} \mathrm{C}$ for $1 \mathrm{~min}$, and then increased to $220^{\circ} \mathrm{C}$ at $10^{\circ} \mathrm{C} \mathrm{min}^{-1}$, and held at $220^{\circ} \mathrm{C}$ for $10 \mathrm{~min}$. The retention time of 2-AP was confirmed at $7.5 \mathrm{~min}$. Each sample had three replicates, and 2-AP conc. was expressed as $\mu \mathrm{g} \mathrm{g}^{-1}$.

\subsubsection{Protein content in rice}

The protein content of rice grains was determined by the Micro-Kjeldahl method using automated nitrogen determination system (14).

\subsubsection{Amylose content in rice}

The amylose content of the rice samples was carried out using method by (15) with some modification. Hundred $\mathrm{mg}$ of the powdered rice sample was taken in a volumetric flask. To which 1 $\mathrm{ml}$ of $95 \%$ ethanol and $9 \mathrm{ml}$ of $1 \mathrm{NaOH}$ was added. It was then heated in boiling water bath to gelatinize starch. Five $\mathrm{ml}$ of the starch extract was taken in $100 \mathrm{ml}$ volumetric flask. One $\mathrm{ml}$ of $1 \mathrm{~N}$ acetic acid and $2 \mathrm{ml}$ iodide solution was added to the starch extract and the volume was made up to $100 \mathrm{ml}$. The solution was shaken and allowed to stand for $20 \mathrm{~min}$. Then the absorbance was measured at $620 \mathrm{~nm}$ using Agilent Technologies Cary 60 UV-VIS spectrophotometer. Then the amylose content of the sample was determined with reference to the standard curve of potato amylose and expressed in percent basis.

\subsection{Statistical Analysis}

Analysis of variance (ANOVA) technique was used to analyze the collected data on different parameters with the help of Statistix 10 (2013) computer program and LSD (Least Significant Difference) test was done to determine the significance in statistical analysis at $5 \%$ level of provability.

\section{Results and Discussion}

\subsection{Effective tillers hill $^{-1}$}

Application of Zn and/or 2-AP had significant effect on number of effective tillers plant ${ }^{-1}$ irrespective of aromatic rice varieties. Between the two varieties, BRRI dhan34 $\left(\mathrm{V}_{1}\right)$ produced the maximum number of effective tillers plant ${ }^{-1}$ compared to that of BRRI dhan80. (Table 1). Generally different cultivars produced different number of effective tillers hill-1 although different biotic and abiotic factors also influenced it. Effective tillers plant ${ }^{-1}$ increased with increasing $\mathrm{Zn}$ level (Table 2), Mustafa (16) also reported maximum productive tillers $\mathrm{m}^{-2}$ increased with increasing its level. On the other hand, 2-AP application had no effect on this parameter (Table $3)$. 
Table 1. Effect of Variety on number of effective tiller/plant and number of filled grains/panicle

\begin{tabular}{ccc}
\hline Variety & $\begin{array}{c}\text { Number of effective } \\
\text { tillers plant }^{-1}\end{array}$ & $\begin{array}{c}\text { Number of filled } \\
\text { grains panicle }^{-1}\end{array}$ \\
\hline $\mathrm{V}_{1}$ & $26.185 \mathrm{a}$ & $180.12 \mathrm{a}$ \\
\hline $\mathrm{V}_{2}$ & $20.889 \mathrm{~b}$ & $105.21 \mathrm{~b}$ \\
\hline $\mathrm{CV}(\%)$ & 13.63 & 15.70 \\
\hline $\mathrm{LSD}_{(0.05)}$ & 1.7745 & 12.392 \\
\hline $\begin{array}{c}\text { Level of } \\
\text { Significance }\end{array}$ & $* *$ & $*$ \\
\hline
\end{tabular}

$\mathrm{V}_{1}=\mathrm{BRRI}$ dhan $34, \mathrm{~V}_{2}=\mathrm{BRRI}$ dhan80

LSD (Least Significant Difference) test was done to determine the significance in statistical analysis at $5 \%(0.05)$ level of provability.

Table 2. Effect of Zinc on number of effective tiller/plant and number of filled grains/panicle

\begin{tabular}{ccc}
\hline Zinc dose & $\begin{array}{c}\text { Number of effective } \\
\text { tillers plant }^{-1}\end{array}$ & $\begin{array}{c}\text { Number of filled } \\
\text { grains panicle }^{-1}\end{array}$ \\
\hline $\mathrm{Zn}_{0}$ & $21.889 \mathrm{~b}$ & 140.31 \\
\hline $\mathrm{Zn}_{1}$ & $23.667 \mathrm{ab}$ & 145.04 \\
\hline $\mathrm{Zn}_{2}$ & $25.056 \mathrm{a}$ & 142.65 \\
\hline $\mathrm{CV}(\%)$ & 13.63 & 15.70 \\
\hline $\mathrm{LSD}(0.05)$ & 2.1733 & 15.177 \\
\hline $\begin{array}{c}\text { Level of } \\
\text { Significance }\end{array}$ & $*$ & $\mathrm{NS}$
\end{tabular}

$\mathrm{Zn}_{0}=10 \mathrm{~kg} \mathrm{ZnSO} / \mathrm{ha}$ (Recommended dose) + $0 \mathrm{~kg} \mathrm{ZnSO}_{4} / \mathrm{ha}$ (supplementation), $\quad \mathrm{Zn}_{1}=10 \mathrm{~kg} \quad \mathrm{ZnSO}_{4} / \mathrm{ha}+2 \mathrm{~kg} \quad \mathrm{ZnSO}_{4} / \mathrm{ha}$ (supplementation), $\quad \mathrm{Zn}_{2}=10 \quad \mathrm{~kg} \quad \mathrm{ZnSO}_{4} / \mathrm{ha}^{+} \quad 4 \quad \mathrm{kgZnSO}_{4} / \mathrm{ha}$ (supplementation)

LSD (Least Significant Difference) test was done to determine the significance in statistical analysis at 5\% (0.05) level of provability.

Table 3. Effect of 2-AP on number of number of effective tillers plant $^{-1}$ and number of filled grains panicle ${ }^{-1}$

\begin{tabular}{|c|c|c|}
\hline 2-AP conc. & $\begin{array}{c}\text { Number of } \\
\text { effective tillers } \\
\text { plant }^{-1}\end{array}$ & $\begin{array}{l}\text { Number of filled } \\
\text { grains panicle }{ }^{-1}\end{array}$ \\
\hline $\mathrm{AP}_{0}$ & 23.833 & 142.93 \\
\hline $\mathrm{AP}_{1}$ & 23.278 & 144.17 \\
\hline $\mathrm{AP}_{2}$ & 23.500 & 140.91 \\
\hline CV (\%) & 13.63 & 15.70 \\
\hline $\operatorname{LSD}_{(0.05)}$ & 2.1733 & 15.177 \\
\hline $\begin{array}{c}\text { Level of } \\
\text { Significance }\end{array}$ & NS & NS \\
\hline
\end{tabular}

$\mathrm{AP}_{0}=0 \mathrm{ml} 2-\mathrm{AP} / \mathrm{L}$ water in $5 \mathrm{~kg}$ pot soil, $\mathrm{AP}_{1}=0.503 \mathrm{ml} 2-\mathrm{AP} / \mathrm{L}$ water in $5 \mathrm{~kg}$ pot soil, $\mathrm{AP}_{2}=1.006 \mathrm{ml}$ 2-AP $/ \mathrm{L}$ water in $5 \mathrm{~kg}$ pot soil

LSD (Least Significant Difference) test was done to determine the significance in statistical analysis at $5 \%(0.05)$ level of provability.

Combined effect of aromatic ice variety, $\mathrm{Zn}$ and 2-AP showed significant differences on effective tillers plant ${ }^{-1}$ (Fig. $1 \& 2$ ). Among the eighteen treatment combinations, the highest number of effective tillers plant ${ }^{-1}$ (29.667) was recorded from $\mathrm{V}_{1} \mathrm{Zn}_{1} \mathrm{AP}_{0}$ and $\mathrm{V}_{1} \mathrm{Zn}_{0} \mathrm{AP}_{0}, \mathrm{~V}_{1} \mathrm{Zn}_{1} \mathrm{AP}_{2}$, $\mathrm{V}_{1} \mathrm{Zn}_{2} \mathrm{AP}_{0}, \quad \mathrm{~V}_{1} \mathrm{Zn}_{2} \mathrm{AP}_{1}, \quad \mathrm{~V}_{1} \mathrm{Zn}_{2} \mathrm{AP}_{2}$ and $\mathrm{V}_{2} \mathrm{Zn}_{2} \mathrm{AP}_{1}$ treatment combinations also showed similar results, while the lowest number (17.33) was observed from $\mathrm{V}_{2} \mathrm{Zn}_{0} \mathrm{AP}_{0}$ treatment combination.3.2 Filled grains panicle ${ }^{-1}$.

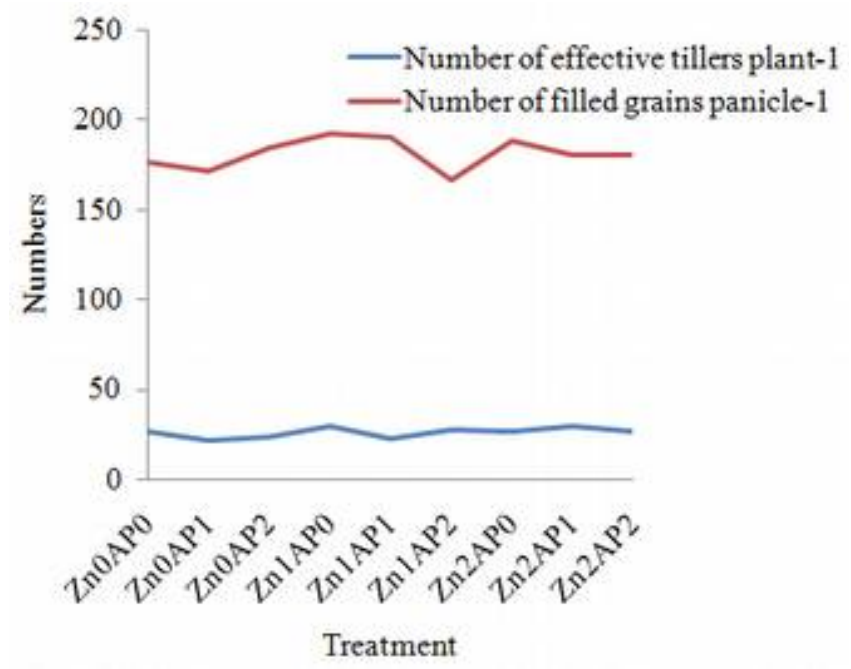

Fig. 1. Interaction effect of zinc and 2-AP on number of effective tillers plant ${ }^{-1}$ and number of filled grains panicle ${ }^{-1}$ of BRRI dhan34

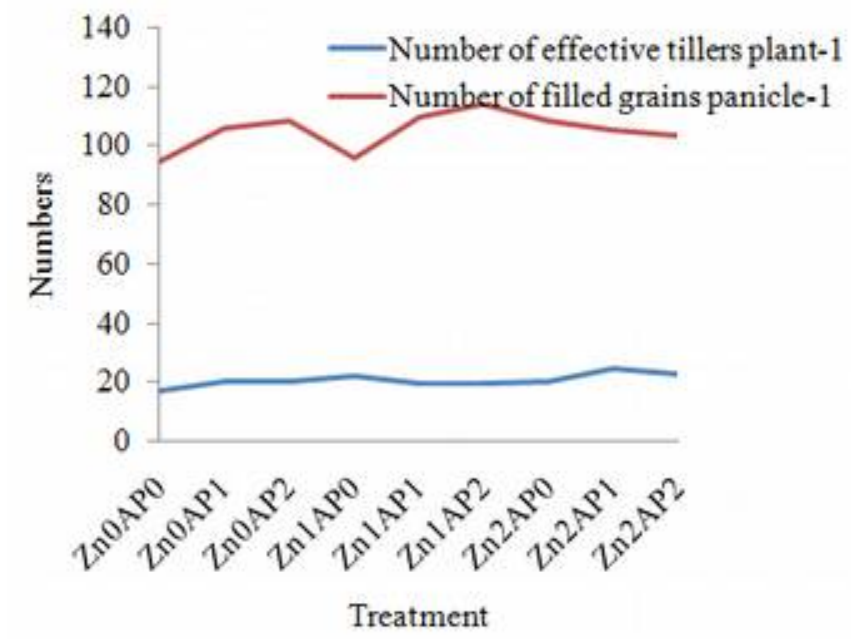

Fig. 2. Interaction effect of zinc and 2-AP on number of effective tillers plant ${ }^{-1}$ and number of filled grains panicle ${ }^{-1}$ of BRRI dhan 80

Statistically significant difference was observed on filled grains panicle ${ }^{-1}$ of two aromatic rice varieties (Table 1 ). The highest number of filled grains panicle ${ }^{-1}$ (180.12) was found in $\mathrm{V}_{1}$ while lowest was recorded in $\mathrm{V}_{2}$ due to genetic performance. But there was no effect on this parameter for application of different levels of $\mathrm{Zn}$ and 2- AP application. Although Lei (17) reported that exogenous application of mixed micro-nutrients $\mathrm{Zn}$ notably increased filled grains. Statistically significant variation was recorded in terms of filled grains panicle ${ }^{-1}$ for different rice varieties (Table 1). The highest number of filled grains panicle ${ }^{-1}$ (185.30) was observed from $\mathrm{V}_{1}$ which was statistically similar (179.47) to $\mathrm{V}_{4}$ and closely followed (176.33) by $\mathrm{V}_{2}$, whereas the lowest number (163.62) was found 
from $V_{3}$. Sarkar (18) revealed that the number of grains panicle ${ }^{-1}$ (152.3) in BRRI dhan34. Combined effect of these treatments showed significant differences on filled grains panicle ${ }^{-1}$ (Fig. 1 \& 2). BRRI dhan34 produced higher number of filled grains panicle ${ }^{-1}$ than BRRI dhan80 irrespective of $\mathrm{Zn}$ and 2-AP levels. Numerically, $\mathrm{V}_{1} \mathrm{Zn}_{1} \mathrm{AP}_{0}$ produced 192.67 filled grains panicle ${ }^{-1}$ and 94.67 was recorded in $\mathrm{V}_{2} \mathrm{Zn}_{0} \mathrm{AP}_{0}$ (Fig. 1 \& 2).

\subsection{Weight of 1000-grains}

Aromatic rice variety had significant effect of 1000- grain weight, but single effect of on $\mathrm{Zn}$ and 2-AP had no effect on this yield contributing parameters. (Tables 4, 5 and 6). Combined effect of rice varieties and different levels of $\mathrm{Zn}$ and 2AP also showed significant effect on 1000-grains weight (Fig. 3 \& 4). The maximum weight of 1000 -grains was found in variety, BRRI dhan 80 $(22.3467-21.367 \mathrm{~g})$ whereas the minimum was recorded in BRRI dhan34 (12.700-12.133 g) irrespective different levels of $\mathrm{Zn}$ and 2-AP (Fig. $3 \& 4)$.

Table 4. Effect of variety grain yield plant ${ }^{-1}$ and 1000 - grains weight

\begin{tabular}{ccc}
\hline Variety & $\begin{array}{c}\text { Grain yield } \\
\text { plant }^{-1}(\mathbf{g})\end{array}$ & $\begin{array}{c}\text { 1000-grains weight } \\
\text { (g) }\end{array}$ \\
\hline $\mathrm{V}_{1}$ & 52.122 & $12.259 \mathrm{~b}$ \\
\hline $\mathrm{V}_{2}$ & 50.755 & $22.067 \mathrm{a}$ \\
\hline $\mathrm{CV}(\%)$ & 15.89 & 5.43 \\
\hline $\mathrm{LSD}_{(0.05)}$ & -- & 0.515 \\
\hline $\begin{array}{c}\text { Level of } \\
\text { Significance }\end{array}$ & $\mathrm{NS}$ & $* *$ \\
\hline
\end{tabular}

$\mathrm{V}_{1}=\mathrm{BRRI}$ dhan $34, \mathrm{~V}_{2}=$ BRRI dhan80

LSD (Least Significant Difference) test was done to determine the significance in statistical analysis at $5 \%(0.05)$ level of provability.

Table 5. Effect of Zinc on grain yield plant ${ }^{-1}$ and 1000- grains weight

\begin{tabular}{ccc} 
Zinc dose & Grain yield plant $^{-1}$ (g) & $\begin{array}{c}\text { 1000- grains weight } \\
\text { (g) }\end{array}$ \\
\hline $\mathrm{Zn}_{0}$ & $45.000 \mathrm{c}$ & 17.361 \\
\hline $\mathrm{Zn}_{1}$ & $51.624 \mathrm{~b}$ & 17.172 \\
\hline $\mathrm{Zn}_{2}$ & $57.692 \mathrm{a}$ & 16.956 \\
\hline $\mathrm{CV}(\%)$ & 15.89 & 5.43 \\
\hline $\mathrm{LSD}(0.05)$ & 5.5356 & - \\
\hline $\begin{array}{c}\text { Level of } \\
\text { Significance }\end{array}$ & $* *$ & $\mathrm{NS}$ \\
\hline
\end{tabular}

$\mathrm{Zn}_{0}=10 \mathrm{~kg} \mathrm{ZnSO}_{4} / \mathrm{ha}\left(\right.$ Recommended dose) $+0 \mathrm{~kg} \mathrm{ZnSO}_{4} / \mathrm{ha}$ (supplementation), $\quad \mathrm{Zn}_{1}=10 \mathrm{~kg} \mathrm{ZnSO}_{4} / \mathrm{ha}+2 \mathrm{~kg} \mathrm{ZnSO}_{4} / \mathrm{ha}$ (supplementation), $\quad \mathrm{Zn}_{2}=10 \mathrm{~kg} \quad \mathrm{ZnSO}_{4} / \mathrm{ha}^{+} \quad 4 \quad \mathrm{kgZnSO}_{4} / \mathrm{ha}$ (supplementation)

LSD (Least Significant Difference) test was done to determine the significance in statistical analysis at 5\% (0.05) level of provability.
Table 6. Effect of 2-AP on grain yield plant ${ }^{-1}$ and 1000- grains weight

2-AP conc. Grain yield plant ${ }^{-1}$ (g) 1000- grains weight (g)

\begin{tabular}{ccc}
\hline $\mathrm{AP}_{0}$ & 50.780 & 17.067 \\
\hline $\mathrm{AP}_{1}$ & 53.341 & 17.383 \\
\hline $\mathrm{AP}_{2}$ & 50.195 & 17.039 \\
\hline $\mathrm{CV}(\%)$ & 15.89 & 5.43 \\
\hline $\mathrm{LSD}_{(0.05)}$ & - & - \\
\hline $\begin{array}{c}\text { Level of } \\
\text { Significance }\end{array}$ & $\mathrm{NS}$ & $\mathrm{NS}$
\end{tabular}

$\mathrm{AP}_{0}=0 \mathrm{ml}$ 2-AP $/ \mathrm{L}$ water in $5 \mathrm{~kg}$ pot soil, $\mathrm{AP}_{1}=0.503 \mathrm{ml} 2-\mathrm{AP} / \mathrm{L}$ water in $5 \mathrm{~kg}$ pot soil, $\mathrm{AP}_{2}=1.006 \mathrm{ml} 2-\mathrm{AP} / \mathrm{L}$ water in $5 \mathrm{~kg}$ pot soil

LSD (Least Significant Difference) test was done to determine the significance in statistical analysis at 5\% (0.05) level of provability.

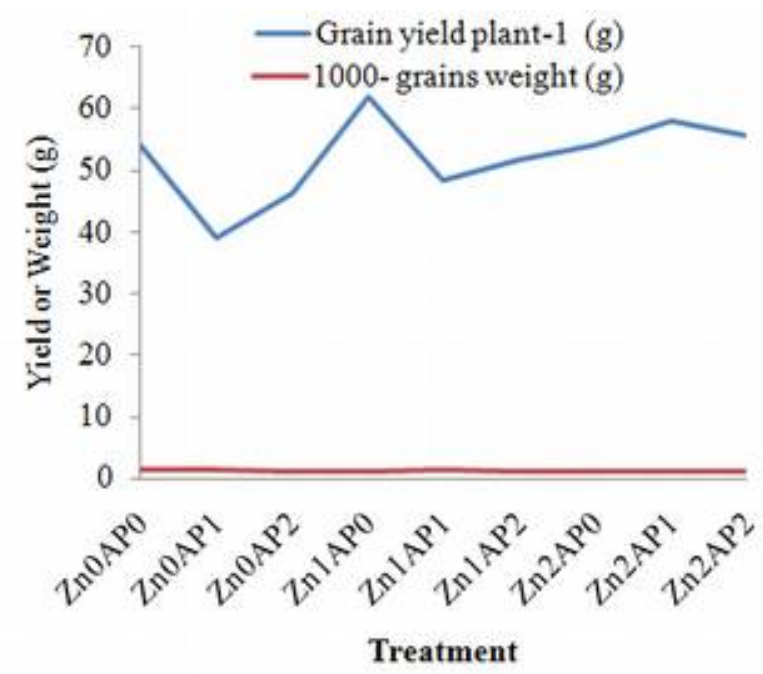

Fig. 3. Interaction effect of zinc and 2-AP on grain yield ${ }^{-1}(\mathrm{~g})$ and 1000-grains weight $(\mathrm{g})$ of BRRI dhan34

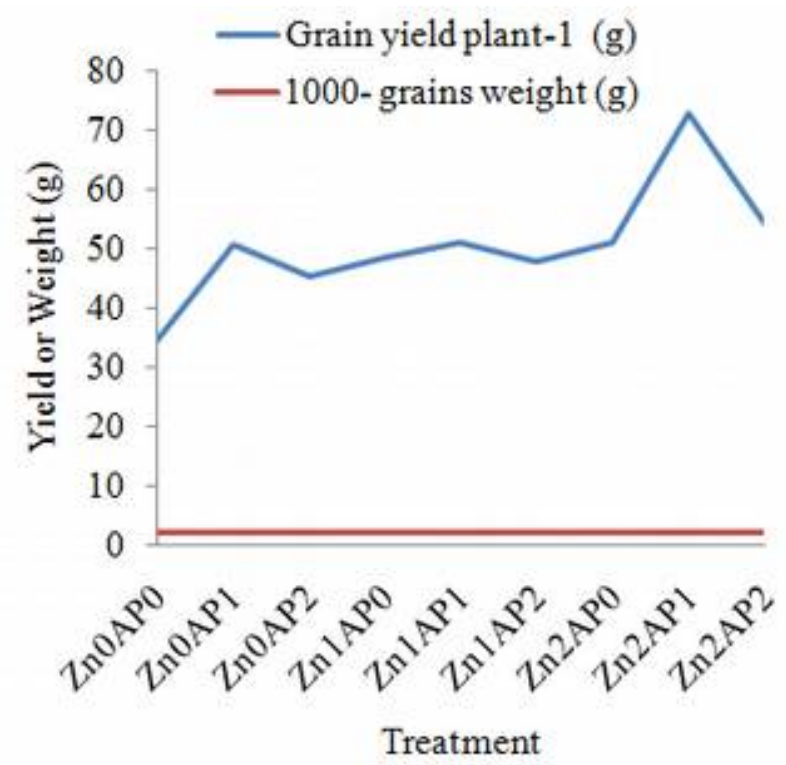

Fig. 4. Interaction effect of zinc and 2-AP on grain yield ${ }^{-1}(\mathrm{~g})$ and 1000-grains weight ( $g$ ) of BRRI dhan 80 


\subsection{Grain yield plant ${ }^{-1}$}

Grain yield plant ${ }^{-1}(\mathrm{~g})$ of aromatic rice varieties showed statistically non-significant differences due to different levels of $\mathrm{Zn}$ and 2-AP (Table 4). Supplementation of $\mathrm{Zn}$ had significant on grain yield plant ${ }^{-1}$ (Table 5 ). The result revealed that grain yield plant ${ }^{-1}$ increased with increasing $\mathrm{Zn}$ level, whereas, the application of 2-AP had no effect on this parameters. The combined effect of variety, $\mathrm{Zn}$ and 2-AP showed significant differences on weight of grain yield plant ${ }^{-1}$ (Fig. 3 \& 4). The combination of $\mathrm{V}_{2} \mathrm{Zn}_{2} \mathrm{AP}_{2}$ produced the highest weight of grain yield plant ${ }^{-1}(72.813 \mathrm{~g})$ which was statistically similar to $\mathrm{V}_{1} \mathrm{Zn}_{1} \mathrm{AP}_{0}$ (61.946) while the lowest was recorded from $\mathrm{V}_{2} \mathrm{Zn}_{0} \mathrm{AP}_{0}$ (34.832) (Fig. $3 \& 4$ ).

\section{$3.5 \mathrm{Zn}$ content in rice}

$\mathrm{Zn}$ content in rice showed statistically significant differences due to different levels of zinc (Table 7). The highest $\mathrm{Zn}$ content $\left(0.154 \mathrm{mg} \mathrm{g}^{-1}\right)$ was found from $\mathrm{Zn}_{2}$ while the lowest $\left(0.113 \mathrm{mg} \mathrm{g}^{-1}\right)$ was observed from $\mathrm{Zn}_{1}$. Studies reported that high zinc groups showed better uptake ability in $\mathrm{Zn}$ content (19). Statistically significant variation was recorded in terms of $\mathrm{Zn}$ content in different rice varieties (Table 8). The highest $\mathrm{Zn}$ content $\left(0.137 \mathrm{mg} \mathrm{g}^{-1}\right)$ was observed from $\mathrm{V}_{2}$ while the lowest $\left(0.123 \mathrm{mg} \mathrm{g}^{-1}\right)$ was found in $\mathrm{V}_{1}$. The 2-AP concentration has significant influence on $\mathrm{Zn}$ content of rice grain (Table 9). The highest $\mathrm{Zn}$ content $(0.141 \%)$ was recorded from $\mathrm{AP}_{2}$ followed by $(0.131 \%)$ to $\mathrm{AP}_{1}$, while the lowest $(0.119 \%)$ was found from $\mathrm{AP}_{0}$. Combined effect of different levels of 2-AP, zinc and rice varieties showed nonsignificant differences on $\mathrm{Zn}$ content in rice (Fig. 5 \& 6). But, numerically the highest $\mathrm{Zn}$ content $\left(0.168 \mathrm{mg} \mathrm{g}^{-1}\right)$ was observed from $\mathrm{V}_{2} \mathrm{Zn}_{2} \mathrm{AP}_{2}$ treatment combination and the lowest $(0.101 \mathrm{mg}$ $\left.\mathrm{g}^{-1}\right)$ was found from $\mathrm{V}_{1} \mathrm{Zn}_{0} \mathrm{AP}_{1}$ treatment combination.

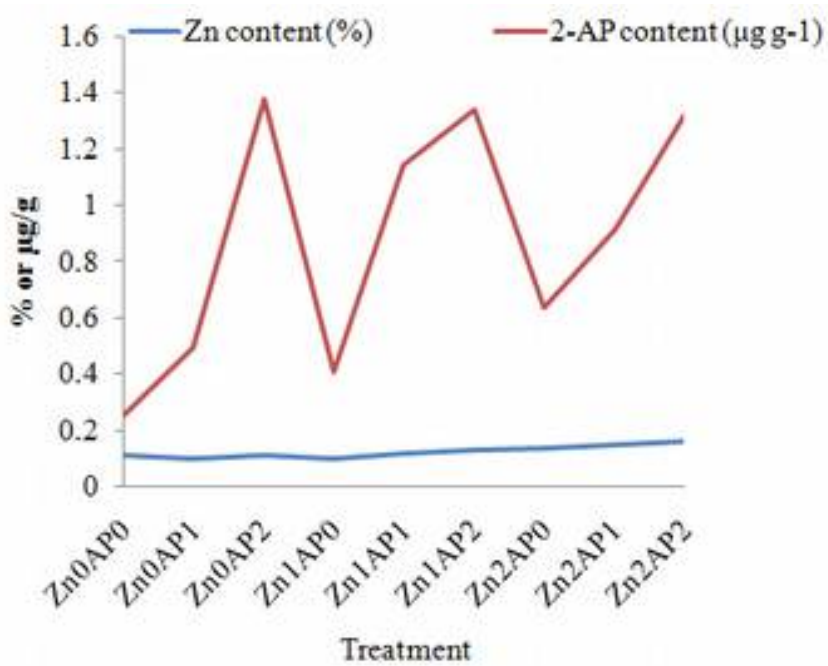

Fig. 5. Interaction effect of zinc and 2-AP on $\mathrm{Zn}$ content (\%) and 2-AP content $\left(\mu \mathrm{g} \mathrm{g}^{-1}\right)$ of BRRI dhan 34

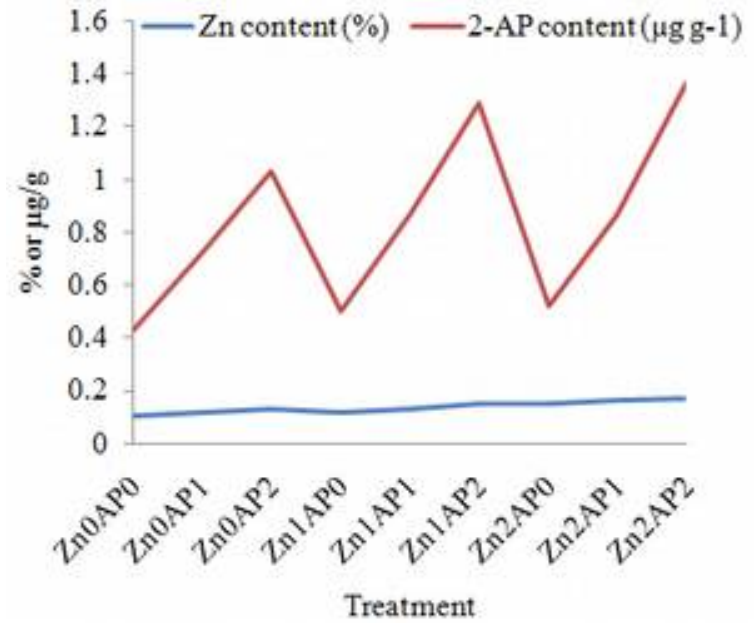

Fig. 6. Interaction effect of zinc and 2-AP on $\mathrm{Zn}$ content (\%) and 2-AP content $\left(\mu \mathrm{g} \mathrm{g}^{-1}\right)$ of BRRI dhan 80

Table 7. Effect of variety on zinc and 2-AP content

\begin{tabular}{ccc}
\hline Variety & Zn content (\%) & 2-AP content $\left(\boldsymbol{\mu \mathbf { g ~ g } ^ { - 1 } )}\right.$ \\
\hline $\mathrm{V}_{1}$ & $0.1239 \mathrm{~b}$ & $0.8772 \mathrm{a}$ \\
\hline $\mathrm{V}_{2}$ & $0.1376 \mathrm{a}$ & $0.8430 \mathrm{~b}$ \\
\hline $\mathrm{CV}(\%)$ & 6.31 & 3.05 \\
\hline $\mathrm{LSD}_{(0.05)}$ & 3.794 & 0.0121 \\
\hline Level of Significance & $* *$ & $* *$
\end{tabular}

$\mathrm{V}_{1}=\mathrm{BRRI}$ dhan $34, \mathrm{~V}_{2}=$ BRRI dhan80

LSD (Least Significant Difference) test was done to determine the significance in statistical analysis at $5 \%(0.05)$ level of provability.

Table 8. Effect of zinc on zinc and 2-AP content

\begin{tabular}{ccc}
\hline Zinc dose & Zn content (\%) & 2-AP content $\left(\boldsymbol{\mu g} \mathbf{~ g}^{-1}\right)$ \\
\hline $\mathrm{Zn}_{0}$ & $0.1131 \mathrm{c}$ & $0.7175 \mathrm{~b}$ \\
\hline $\mathrm{Zn}_{1}$ & $0.1243 \mathrm{~b}$ & $0.9244 \mathrm{a}$ \\
\hline $\mathrm{Zn}_{2}$ & $0.1547 \mathrm{a}$ & $0.9383 \mathrm{a}$ \\
\hline $\mathrm{CV} \mathrm{( \% )}$ & 6.31 & 3.05 \\
\hline $\mathrm{LSD}_{(0.05)}$ & 5.442 & 0.0173
\end{tabular}

Level of Significance

$\mathrm{Zn}_{0}=10 \mathrm{~kg} \mathrm{ZnSO} / / \mathrm{ha}($ Recommended dose) $+0 \mathrm{~kg} \mathrm{ZnSO} / \mathrm{ha}$ (supplementation), $\mathrm{Zn}_{1}=10 \mathrm{~kg} \mathrm{ZnSO}_{4} / \mathrm{ha}+2 \mathrm{~kg} \mathrm{ZnSO}_{4} / \mathrm{ha}$ (supplementation), $\mathrm{Zn}_{2}=10 \mathrm{~kg} \mathrm{ZnSO} / / \mathrm{ha}+4 \mathrm{kgZnSO}_{4} / \mathrm{ha}$ (supplementation)

LSD (Least Significant Difference) test was done to determine the significance in statistical analysis at 5\% (0.05) level of provability.

Table 9. Effect of 2-AP concentration on zinc and 2-AP content

\begin{tabular}{ccc}
\hline 2-AP conc. & Zn content (\%) & 2-AP content $\left(\boldsymbol{\mu} \mathbf{g ~ g}^{-1}\right)$ \\
\hline $\mathrm{AP}_{0}$ & $0.1194 \mathrm{c}$ & $0.4581 \mathrm{c}$ \\
\hline $\mathrm{AP}_{1}$ & $0.1313 \mathrm{~b}$ & $0.8356 \mathrm{~b}$ \\
\hline $\mathrm{AP}_{2}$ & $0.1414 \mathrm{a}$ & $1.2867 \mathrm{a}$ \\
\hline $\mathrm{CV}(\%)$ & 6.31 & 3.05 \\
\hline $\mathrm{LSD}(0.05)$ & 5.442 & 0.0173 \\
\hline $\begin{array}{c}\text { Level of } \\
\text { Significance }\end{array}$ & $* *$ & $* *$ \\
\hline
\end{tabular}

$\mathrm{AP0}=0 \mathrm{ml}$ 2-AP $/ \mathrm{L}$ water in $5 \mathrm{~kg}$ pot soil, $\mathrm{AP} 1=0.503 \mathrm{ml}$ 2-AP $/ \mathrm{L}$ water in $5 \mathrm{~kg}$ pot soil, AP2 $=1.006 \mathrm{ml}$ 2-AP $/ \mathrm{L}$ water in $5 \mathrm{~kg}$ pot soil

LSD (Least Significant Difference) test was done to determine the significance in statistical analysis at 5\% (0.05) level of provability. 


\subsection{Grain-2AP content in rice}

Grain 2-AP content in rice showed statistically significant differences due to different levels of zinc (Table 7). The highest grain-2AP content $(0.938 \mu \mathrm{g}$ g $\left.{ }^{1}\right)$ was observed from $\mathrm{Zn}_{2}$ which was statistically similar $\left(0.924 \mu \mathrm{g} \mathrm{g}^{-1}\right)$ to $\mathrm{Zn}_{1}$, whereas the lowest $\left(0.717 \mu \mathrm{g} \mathrm{g}^{-1}\right)$ was recorded from $\mathrm{Zn}_{0}$. Statistically significant variation was recorded in terms of grain-2AP content in different rice varieties (Table 8). The highest grain-2AP content $\left(0.877 \mu \mathrm{g} \mathrm{g}^{-1}\right)$ was found from $V_{1}$ while the lowest $\left(0.842 \mu \mathrm{g} \mathrm{g}^{-1}\right)$ was recorded from $\mathrm{V}_{2}$. The 2-AP concentration has significant influence on grain 2-AP content of rice grain (Table 9). The highest grain 2-AP content (1.286\%) was recorded from $\mathrm{AP}_{2}$ followed by $(0.835 \%)$ to $\mathrm{AP}_{1}$, while the lowest $(0.458 \%)$ was found from $\mathrm{AP}_{0}$. Combined effect of different levels of zinc, 2-AP and rice varieties showed significant differences on grain-2AP content in rice (Fig. $5 \& 6$ ). The highest grain-2AP content $\left(1.376 \mu \mathrm{g} \mathrm{g}^{-1}\right)$ was recorded from $\mathrm{V}_{1} \mathrm{Zn}_{0} \mathrm{AP}_{2}$ treatment combination which was statistically similar to $\mathrm{V}_{2} \mathrm{Zn}_{2} \mathrm{AP}_{2}$ and $\mathrm{V}_{1} \mathrm{Zn}_{1} \mathrm{AP}_{2}$, whereas the lowest $\left(0.255 \mu \mathrm{g} \mathrm{g}^{-1}\right)$ was observed from $\mathrm{V}_{1} \mathrm{Zn}_{0} \mathrm{AP}_{0}$ treatment combination.

\subsection{Protein content in rice}

Protein content in rice showed statistically significant differences due to different levels of zinc (Table 10$)$. The highest protein content $(9.00 \%)$ was recorded from $\mathrm{Zn}_{2}$ which was statistically similar (8.91) to $\mathrm{Zn}_{1}$, while the lowest $(8.85 \%)$ was found from $\mathrm{Zn}_{0}$. Statistically significant variation was recorded in terms of protein content in different rice varieties (Table 11). The highest protein content $(9.05 \%)$ was found from $V_{1}$, whereas the lowest (8.79\%) was observed from $\mathrm{V}_{2}$. The 2-AP concentration has significant influence on protein content of rice grain (Table 12). The highest protein content $(9.10 \%)$ was recorded from $\mathrm{AP}_{2}$ followed by (8.89\%) to $\mathrm{AP}_{1}$, while the lowest $(8.77 \%)$ was found from $\mathrm{AP}_{0}$. Combined effect of different levels of 2$\mathrm{AP}$, zinc and rice varieties showed non-significant differences on protein content in rice (Fig. $7 \& 8$ ). But numerically the highest protein content (9.32\%) was observed from $\mathrm{V}_{1} \mathrm{Zn}_{1} \mathrm{AP}_{1}$ treatment combination which was statistically similar (90.26) to $\mathrm{V}_{1} \mathrm{Zn}_{2} \mathrm{AP}_{2}$, while the lowest $(8.62 \%)$ was found from $\mathrm{V}_{2} \mathrm{Zn}_{0} \mathrm{AP}_{0}$ treatment combination.

Table 10. Effect of varity on protein and amylose content

\begin{tabular}{ccc}
\hline Variety & Protein content (\%) & Amylose content (\%) \\
\hline $\mathrm{V}_{1}$ & $9.0537 \mathrm{a}$ & 23.668 \\
\hline $\mathrm{V}_{2}$ & $8.7956 \mathrm{~b}$ & 23.821 \\
\hline $\mathrm{CV}(\%)$ & 1.99 & 2.30 \\
\hline $\mathrm{LSD}_{(0.05)}$ & 0.0982 & 0.3023 \\
\hline $\begin{array}{c}\text { Level of } \\
\text { Significance }\end{array}$ & $* *$ & $\mathrm{NS}$ \\
\hline
\end{tabular}

$\mathrm{V}_{1}=\mathrm{BRRI}$ dhan34, $\mathrm{V}_{2}=\mathrm{BRRI}$ dhan80

LSD (Least Significant Difference) test was done to determine the significance in statistical analysis at $5 \%(0.05)$ level of provability.
Table 11. Effect of zinc on protein content and amylose content

\begin{tabular}{ccc}
\hline Zinc dose & Protein content (\%) & Amylose content (\%) \\
\hline $\mathrm{Zn}_{0}$ & $8.8539 \mathrm{~b}$ & 23.717 \\
\hline $\mathrm{Zn}_{1}$ & $8.9117 \mathrm{ab}$ & 23.724 \\
\hline $\mathrm{Zn}_{2}$ & $9.0083 \mathrm{a}$ & 23.792 \\
\hline $\mathrm{CV}(\%)$ & 1.99 & 2.30 \\
\hline $\mathrm{LSD}(0.05)$ & 0.1203 & 0.3702 \\
\hline $\begin{array}{c}\text { Level of } \\
\text { Significance }\end{array}$ & $*$ & $\mathrm{NS}$ \\
\hline
\end{tabular}

$\mathrm{Zn}_{0}=10 \mathrm{~kg} \mathrm{ZnSO}_{4} /$ ha(Recommended dose) $+0 \mathrm{~kg} \mathrm{ZnSO} / \mathrm{ha}$ (supplementation), $\mathrm{Zn}_{1}=10 \mathrm{~kg} \mathrm{ZnSO}_{4} / \mathrm{ha}+2 \mathrm{~kg} \mathrm{ZnSO}_{4} / \mathrm{ha}$ (supplementation), $\mathrm{Zn}_{2}=10 \mathrm{~kg} \mathrm{ZnSO} / / \mathrm{ha}+4 \mathrm{kgZnSO}_{4} / \mathrm{ha}$ (supplementation)

LSD (Least Significant Difference) test was done to determine the significance in statistical analysis at 5\% (0.05) level of provability.

Table 12. Effect of 2-AP concentration on protein content and amylose content

\begin{tabular}{ccc}
\hline 2-AP conc. & Protein content (\%) & Amylose content (\%) \\
\hline $\mathrm{AP}_{0}$ & $8.7772 \mathrm{~b}$ & $23.268 \mathrm{c}$ \\
\hline $\mathrm{AP}_{1}$ & $8.8933 \mathrm{~b}$ & $23.666 \mathrm{~b}$ \\
\hline $\mathrm{AP}_{2}$ & $9.1033 \mathrm{a}$ & $24.299 \mathrm{a}$ \\
\hline $\mathrm{CV}(\%)$ & 1.99 & 2.30 \\
\hline $\mathrm{LSD}(0.05)$ & 0.1203 & 0.3702 \\
\hline $\begin{array}{c}\text { Level of } \\
\text { Significance }\end{array}$ & $* *$ & $* *$ \\
\hline
\end{tabular}

$\mathrm{AP}_{0}=0 \mathrm{ml}$ 2-AP $/ \mathrm{L}$ water in $5 \mathrm{~kg}$ pot soil, $\mathrm{AP}_{1}=0.503 \mathrm{ml} 2-\mathrm{AP} / \mathrm{L}$ water in $5 \mathrm{~kg}$ pot soil, $\mathrm{AP}_{2}=1.006 \mathrm{ml}$ 2-AP $/ \mathrm{L}$ water in $5 \mathrm{~kg}$ pot soil

LSD (Least Significant Difference) test was done to determine the significance in statistical analysis at $5 \%(0.05)$ level of provability.

\subsection{Amylose content in rice}

Amylose content in rice showed statistically nonsignificant differences due to different levels of zinc (Table 10). The highest amylose content (23.35\%) was recorded from $\mathrm{Zn}_{4}$ and the lowest $(22.18 \%)$ was observed from $\mathrm{Zn}_{1}$. Statistically significant variation was recorded in terms of amylose content in different rice varieties (Table 11). The highest amylose content (24.99\%) was observed from $\mathrm{V}_{3}$, while the lowest $(21.93 \%)$ was found from $V_{1}$ which was statistically similar (21.97\% and 22.28\%) to $\mathrm{V}_{4}$ and $\mathrm{V}_{2}$. The 2-AP concentration has significant influence on amylose content of rice grain (Table 12). The highest amylose content $(24.29 \%)$ was recorded from $\mathrm{AP}_{2}$ followed by $(23.66 \%)$ to $\mathrm{AP}_{1}$, while the lowest (23.26\%) was found from $\mathrm{AP}_{0}$. Combined effect of different levels of zinc and rice varieties showed non-significant differences on amylose content in rice (Fig. 7 \& 8). But numerically the highest amylose content (26.05\%) was recorded from $\mathrm{Zn}_{4} \mathrm{~V}_{3}$ treatment combination, whereas the lowest (20.86\%) was observed from $\mathrm{Zn}_{1} \mathrm{~V}_{2}$ treatment combination. 


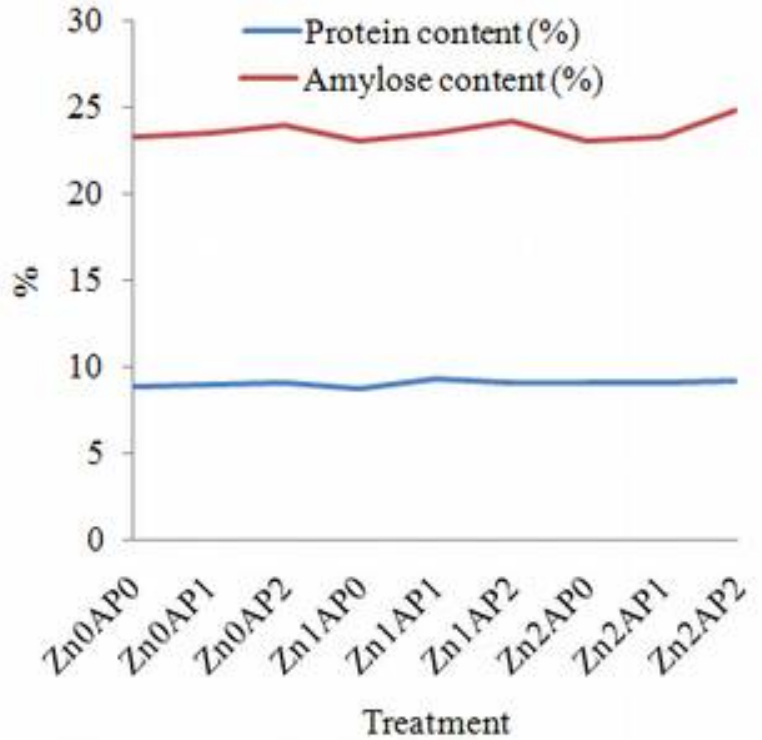

Fig. 7. Interaction effect of zinc and 2-AP on protein content (\%) and Amylose content (\%) of BRRI dhan34

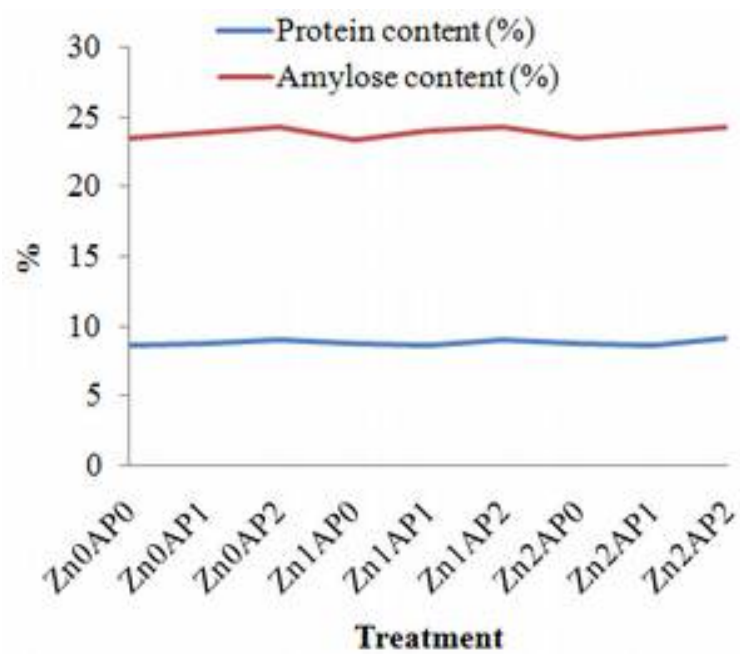

Fig. 8: Interaction effect of zinc and 2-AP on protein content (\%) and Amylose content (\%) of BRRI dhan80

\subsection{Discussion}

The study mostly emphasize on effect of $\mathrm{Zn}$ and 2AP on yield and quality of popular aromatic rice variety of Bangladesh. Some nutrients viz., N, P, $\mathrm{Zn}, \mathrm{Ca}, \mathrm{Mg}$ and $\mathrm{Mn}$ could enhance the yield and quality of rice (20). 2-AP biosynthesis and accumulation in rice is an important phenomenon that is affected by several factors and the location for rice cultivation is affected on 2-AP contents (8). As expected, we have successfully investigated the effects of Zn and 2-AP on Zn, 2-AP, protein and amylose content. In present study, addition of Zn and 2-AP show the higher 2AP, Zn, protein content compared to those of no supplementation of $\mathrm{Zn}$ and 2-AP. Zn and 2-AP affected the ProDH activity resulted in proline conversion to 1-pyrroline-5carboxylic acid then converted to 2-AP (21). Our observations regarding $\mathrm{Zn}$ and 2-AP induced changes in grain 2-AP concentrations of grains tell us that both elements may be involved in complicated biosynthetic mechanisms of aroma formation directly, or the elements might have indirect effects on 2-AP biosynthesis through regulation of enzymatic activities involved in 2-AP formation. Furthermore, the bio-chemical pathways leading to 2-AP biosynthesis are quite complicated and have not been fully resolved yet. Different mechanisms have been reported. For instance, the pathway might work as follows: conversion of proline, glutamic acid and ornithine to 1-pyrroline-5-carboxylic acid by proline dehydrogenase, pyrroline-5-carboxylic acid synthetase and ornithine aminotrans-ferase, respectively, followed by conversion to 2-AP via enzymatic (acetyl-CoA groups) or non-enzymatic (methylglyoxal) pathways (22). The results of this study indicate that higher grain 2-AP concentrations in grain seem to be due to increased transportation of 2-AP from the soil into grains. The increased $\mathrm{Zn}$ concentration is due to $\mathrm{Zn}$ supplementation. Application of both $\mathrm{Zn}$ and 2$\mathrm{AP}$ at high levels might be helpful for enhancing rice aroma, and this supplementation can be easily practiced. To explore the possible roles of $\mathrm{Zn}$ and 2-AP in rice aroma formation and its interactions with physico-chemical processes of 2-AP biosynthesis, intensive research is needed at the molecular level.

\subsection{Coefficient of Determinant $\left(\mathbf{R}^{2}\right)$}

Correlation analyses showed significant positive relation among grain 2-AP, protein and amylase content of grain in response to zinc application for both rice cultivars. There was a positive relation $\left(\mathrm{R}^{2}=0.2688\right)$ of between zinc content $(\mathrm{g})$ and grain yield per plant (g) (Fig. 9). Sarwar (23) reported that with the increase in dose level from $20 \mathrm{~kg}$ to $30 \mathrm{~kg} \mathrm{Zn} \mathrm{ha}^{-1}$, there was corresponding increase in grain yield regardless of the two varieties. A positive linear relation $\left(\mathrm{R}^{2}=0.2689\right)$ was found between zinc content (g) and grain 2-AP content ( $\mu \mathrm{g} \mathrm{g}^{-1}$ ) (Fig. 10). Mo et al. (24) observed that a positive and significant relation between supplementation of zinc and increment of grain 2AP content in aromatic rice. A positive linear relation $\left(\mathrm{R}^{2}=0.0774\right)$ was found between zinc content (g) and grain protein content $\left(\mu \mathrm{g} \mathrm{g}^{-1}\right)$ (Fig. 11). It was observed that the application of nitrogen along with zinc significantly increased protein content of rice grain (25). The results supported the findings of present study. In Fig. 12,

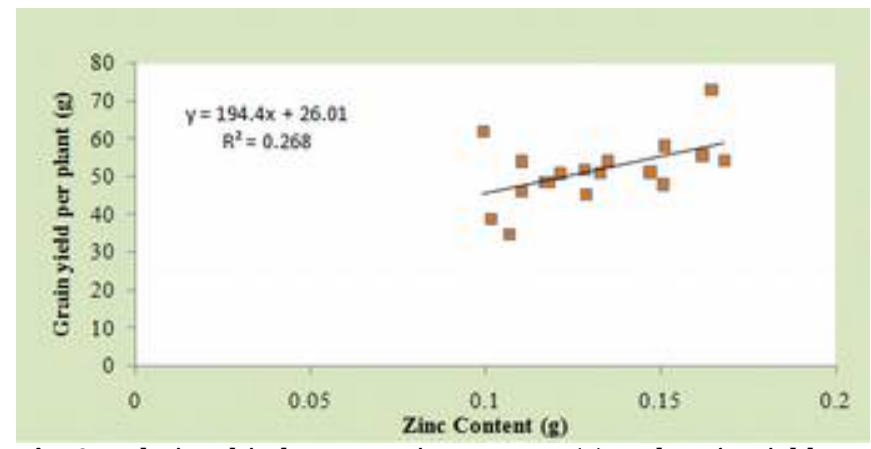

Fig. 9. Relationship between zinc content (g) and grain yield per plant (g) 
a positive linear relation $\left(\mathrm{R}^{2}=0.2556\right)$ between zinc content (g) and grain alylose (\%). It was found that amylose content was significantly and linearly increased with increasing zinc application rates (26).

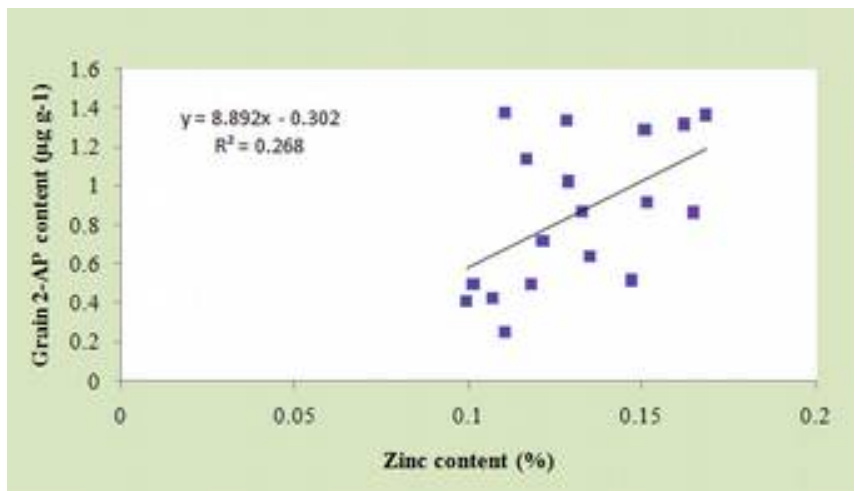

Fig. 10. Relationship between zinc content (g) and grain 2-AP content $\left(\mu \mathrm{g} \mathrm{g}^{-1}\right)$

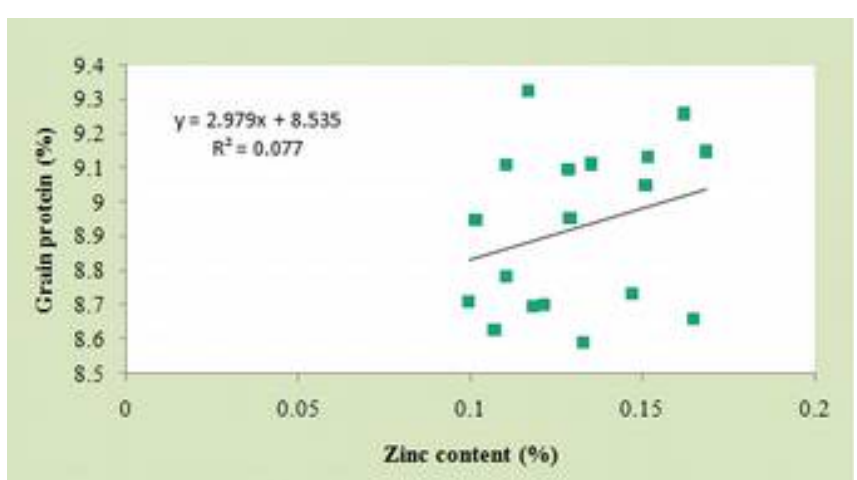

Fig. 11. Relationship between zinc content (g) and grain protein (\%)

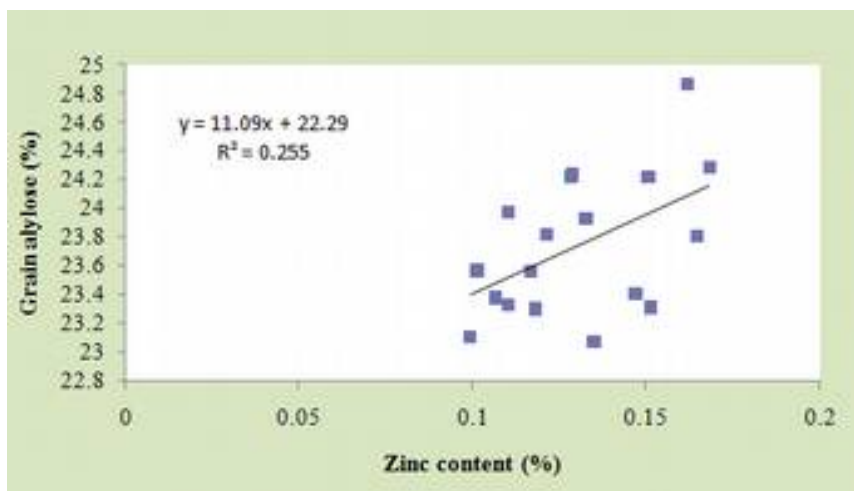

Fig. 12. Relationship between zinc content (g) and grain alylose (\%)

\section{Conclusion}

The experiment illustrated the effect of $\mathrm{Zn}$ and 2AP on yield and quality of Bangladeshi fragrant rice. It was found that supplementation of $\mathrm{Zn}$ and 2-AP had no significant effect on most of the yield contributing parameters. In this study, we demonstrated that supplementation of $\mathrm{Zn}$ and 2AP significantly increased Zn, 2-AP, protein and amylose content. Transformation of 2-AP, directly from the soil due to $\mathrm{Zn}$ supplementation might also be responsible for the higher grain 2-AP concentration. Thus, Zn might have some relationship with 2-AP formation; however, more critical researches are still needed to understand exactly how $\mathrm{Zn}$ is involved in 2-AP formation. It may be concluded that a good management can also increase $\mathrm{Zn}$, protein, amylose content in fragrant rice.

\section{Conflict of Interest}

No part of this research has been published elsewhere in any form. So, the authors declared that they have no conflict of interest.

Acknowledgements: This study was supported by the University Grants Commission of Bangladesh for financial help (Grant ID: Agriculture (Crop28/2017).

\section{Author's contribution}

Dr. Roy and Mr. Chakraborty thought the research ideas. Dr. Roy, Mr. Chakraborty and Mr. Anup conducted the research. Mr. Mostofa, Mr. Mahato, Mr. Sumon and Mrs. Sultana helped during data collection. Mr. Chakraborty analyzed the data. Dr. Roy and Mr. Chakraborty interpreted the data and drafted, read. Dr. Roy and Dr. Ali approved the final manuscript. After all, Dr. Roy supervised the team work and reviewed the manuscript to make a good frame work. After all, the authors were afforded their efficiency to the research work at the level best.

\section{References}

1. The Financial Express. Imported fine varieties making inroads into local rice market (https://thefinancialexpress.com.bd/trade/imported-finevarieties-making-inroads-into-local-rice-market$\underline{1526064965} 2018$ (Retrieved on 9 September, 2019).

2. Mahmud I. Bangladesh not in a position to export rice: IFPRI.

https://en.prothomalo.com/bangladesh/news/196565/Ban gladesh-not-in-aposition-to-export-rice-IFPRI 2019 (Retrieved on 11 September, 2019).

3. Islam M, Rafiqul BAA, Mustafi A, Hossain M. Socioeconomic aspects of Fine quality rice cultivation in Bangladesh Rice Research Prioritization. 1996.

4. Mathure SV, Wakte KV, Jawali N, Nadaf AB. Quantification of 2-Acetyl-1- pyrroline and Other Rice Aroma Volatiles Among Indian Scented Rice Cultivars by HS-SPME/GCFID. Food Anal Methods. 2011;4:326-33. https://doi.org/10.1007/s12161-010-9171-3

5. Mathure SV, Jawali N, Thengane RJ, Nadaf AB. Comparative quantitative analysis of headspace volatiles and their association with BADH2 marker in nonbasmati scented, basmati and non-scented rice (Oryza sativa L.) cultivars of India. Food Chem. 2014;142:383-91. https://doi.org/10.1016/j.foodchem.2013.07.066

6. Sriseadka T, Wongpornchai S, Kitsawatpaiboon P. Rapid method for quantitative analysis of the aroma impact compound, 2-acetyl-1-pyrroline in fragrant rice using 
automated headspace gas chromatography. J Agric Food Chem. 2006;54:8183-89. https://doi.org/10.1021/jf0614490

7. Maraval I, Sen K, Agrebi A, et al. Quantification of 2-acetyl1-pyrroline in rice by stable isotope dilution assay through headspace solid-phase microextraction coupled to gas chromatography-tandem mass spectrometry. Anal Chim Acta. 2010;675:148-55. https://doi.org/10.1016/j.aca.2010.07.024

8. Yoshihashi T, Nguyen TTH, Kabaki N. Area dependency of 2-acetyl-1-pyrroline content in an aromatic rice variety, Khao Dawk Mali 105. JARQ-JPNAgr. Res. 2002;38:105-09. https://doi.org/10.6090/jarq.38.105

9. Yoshihashi T. Does drought condition induce the aroma quality of aromatic rice. Japan International Research Center for Agricultural Sciences, Food Sci. Divn. News Letter for Intl. Collaboration. 2005;45:4.

10. Shivay YS, Prasad R, Rahal A. Genotypic variation for productivity, zinc utilization efficiencies, and kernel quality in aromatic rices under low available zinc conditions. J Plant Nutr. 2010;33(12):1835-48. https://doi.org/10.1080/01904167.2010.503832

11. Yadi R, Dastan S, Yasari E. Role of zinc fertilizer on grain yield and some qualities parameters in Iranian rice genotypes. Ann Biol Res. 2012;3(9):4519-27.

12. Prasad R. Zinc in soils and in plants, human \& animal nutrition. Indian J Fertil. 2006;2(9):103-19.

13. Huang ZL, Tang XR, Wang YL, Chen MJ, Zhao ZK, Duan MY. Effects of increasing aroma cultivation on aroma and grain yield of aromatic rice and their mechanism. Sci Agric Res. 2012;45(6):1054-65.

14. AOAC-Association of official Analytical Chemist. Official Methods of Analysis. Association of official Analytical Chemist (15th edn), AOAC, Washington, DC, USA. J Agric Food Chem. 1990;36(5):1006-09.

15. Juliano. A simplified assay for milled rice amylose. Cereal Sci Today. 1971;16:334-38.

16. Mustafa G, Enshanullah, Akbar N, Qaisrani SA, Iqbal A, Khan ZH, et al. Effect of zinc application on growth and yield of rice. Intl J Agro Vet Med Sci. 2011;5(6):530-35. https://doi.org/10.5455/ijavms.9383

17. Lei S, Wang CC, Ashraf U, Mo ZW, Nawaz M, Ashraf I, Muzaffar W, Liu SJ, Tang XR. Exogenous application of mixed micro-nutrients improves yield, quality, and 2 Acetyl-1-Pyrroline contents in fragrant rice. Appl Ecol Env Res. 2017;15(3):1097-09. https://doi.org/10.15666/aeer/1503 10971109

18. Sarkar SK, Sarkar MAR, Islam N, Paul SK. Yield and quality of aromatic fine rice as affected by variety and nutrient management. J Bangladesh Agril Univ. 2014;12(2):279-84. https://doi.org/10.3329/jbau.v12i2.28683

19. Kabeya MJ, Shankar AG. Effect of different levels of zinc on growth and uptake ability in rice zinc contrast lines (Oryza Sativa L.). Asian J Plant Sci Res. 2013;3(3):112-16.

20. Indira C. Effect of nitrogen fertilizer on growth, yield and quality of hybrid rice (Oryza sativa). J Cent Eur Agr. 2005;6(4):611-18.

21. Huang TC, Huang YW, Hung HJ, Ho CT, Wu ML. 1Pyrroline-5-carboxylic acid formed by proline dehydrogenase from the Bacillus subtilis ssp. natto expressed in Escherichia coli as a precursor for 2-acetyl1-pyrroline. J Agric Food Chem. 2007;55(13):5097-02. https://doi.org/10.1021/jf0700576

22. Huang JX, Xiao D, Duan MY, Tian H, Li GX, Zhong KY. Effects of different applications of $\mathrm{zncl}_{2}$ on the yield and aroma content of aromatic rice. Acta Agriculturae Boreali-Sinica. 2008;23(10):290-92.

23. Sarwar M. Effects of Zinc fertilizer application on the incidence of rice stem borers (Scirpophaga species) (Lepidoptera: Pyralidae) in rice (Oryza sativa L.) crop. J Cereals Oilseeds. 2008;2(1):61-5.

24. Mo Z, Huang J, Xiao D, Ashraf U, Duan M, Pan S, Tang X. Supplementation of 2-Ap, Zn and La improves 2-acetyl-1pyrroline concentrations in detached aromatic rice panicles in vitro. PloS one. 2016;11(2):1-15. https://doi.org/10.1371/journal.pone.0149523

25. Jiang W, Struik PC, Van Keulen H, Zhao M, Jin LN, Stomph TJ. Does increased zinc uptake enhance grain zinc mass concentration in rice? Ann Appl Biol. 2008;153(1):135-47. https://doi.org/10.1111/j.1744-7348.2008.00243.x

26. Hasnain Z, Ali H. Kernel quality and morphological traits of scented rice (cv. Super Basmati) in relation to irrigation and zinc application. J Plant Breed Crop Sci. 2013;5(9):187-94. https://doi.org/10.5897/JPBCS2013.0412 